\title{
THE ROLE OF LOCAL GOVERNMENTS IN CONTAINING COVID-19 IN ETHIOPIA
}

https://doi.org/10.47743/jopafl-2021-20-04

\author{
Nigussie DABA H. \\ School of Policy Studies, College of Leadership and Governance, Ethiopian Civil Service \\ University, \\ Addis Ababa, Ethiopia \\ dabanigussie@gmail.com
}

\begin{abstract}
Drawing from qualitative analysis of constitutions, proclamations, archival documents and interview results, the study examines the role of local governments in containing coronavirus (COVID-19) epidemic in Oromia regional state and Addis Ababa city Administration based on their powers and functional competences. It analyzes the efforts made by the local governments in containing coronavirus pandemic. The analysis indicates that the federal government has broad policy making power, and as a result, can impact local government actions. The regional governments and zonal administrations also oversee the activities of local governments through the respective sectoral bureaus. In addition, local governments in Ethiopia do not have adequate protection under the FDRE Constitution. However, their role in mitigating the corona virus pandemic and similar pandemics in the future cannot be undermined. The study also reveals that, during this COVID-19 pandemic, most of the activities are all managed from the center by a centralized task force which has a governance structure at federal, regional and local levels for decision making around the pandemic and meant to co-ordinate all the activities. This shows that the role of local governments is insignificant, and limited only to implementation as every activity is under the command of ministerial committee. Hence, both senior levels of governments are playing key roles in local governments' actions. Finally this paper recommends strengthening local systems and building the capacity of local governments to manage the policy responses and to improve their role as laboratories of innovative ideas and encouraging them to initiate new ideas and methods of confronting local problems such as coronavirus (COVID-19).

Keywords: Local Governance, Corona Virus, Federal Government, Policy Power, Addis Ababa, Oromia, Ethiopia
\end{abstract}

\section{Introduction}

\section{Background of the Study}

The coronavirus (COVID-19) disease is creating enormous stress on the health care system of almost all nations in the world. The pandemic is also causing social, political and economic impacts on the people. The coronavirus (COVID-19) outbreak was declared a global pandemic by the World Health Organization (WHO) on 11 March 2020. The virus was first known in Ethiopia when a person who came from Burkina Faso, Japanese by nationality, was tested and found positive on 13 March 2020. After the first state of COVID-19 in Ethiopia in March 2020, the Ethiopian Government passed different decisions and has taken different policy measures such as closing schools, limiting large gatherings, and restricting number of passengers in mass transport such as city buses to contain increased levels of infection. The federal, state, and local governments are introducing various actions with the affirmed purpose of containing the spread of the virus. While the effect of the crisis is highly visible in terms of local public health and socioeconomic imbalances, other local democratic values including participatory practices, 
transparency and accountability could also be influenced by the enacted restrictions (Moolakkattu, 2020).

Immediately after the first definite situation of COVID-19 in Ethiopia in March 2020, the Ethiopian Government passed some decisions and has taken different policy measures to contain increased levels of infection. These comprised closing all schools and limiting big meetings and mobility of persons. The government officials at federal and regional states have repeatedly communicated the main prevention measures such as handwashing and social distancing to the general public via numerous media outlets.

Currently more than 1.3 million persons are tested, and the persons infected with the virus reached more than 79, 437 in Ethiopia. Number of individuals who died due to the virus also reached more than 1230 while 34,016 of infected person were recovered. These numbers are also increasing very fast on the daily basis and the disease is also spreading to almost all regional states and cities in the country. Globalization could be considered as one of the main reasons for the fast spread of COVID-19 worldwide. The massive transportations systems, the free trade liberalization and labor mobility could escalate the spread of coronavirus (COVID-19) globally. Contagious causes could also take advantage of the dramatic population flow facilitated by the advance in transportation, to reach out to everywhere in the world (Estrada and Khan 2020).

Although the crisis' impact has been most noticeable in terms of local public health and socioeconomic inequalities, other local democratic principles such as participatory practices, transparency and accountability could also be affected by the imposed restrictions. Better governance is critical for fighting infectious disease transmission in this globalized world. As complex as the epidemic itself, infectious disease control presents significant governance challenges. It is thus vital to understand how states place themselves in the architecture of global epidemics control. Governments need to set up a functional system to face up the challenge. Timely intrusions with high political commitment and community mobilization are believed to assist in preventing the incidence of numerous cases and deaths. Local governments also have great roles in the governance. Without real functioning local governments, the role of nations in controlling global infectious diseases cannot be realized.

Local governments play a key role in establishing healthy and safe work environment, creating jobs, sustainable local economic development, and a stable political climate. Local governments in federal systems do not have similar place and role as some federations constitutionally recognize their local governments while others leave such functions and competences for the regional states or provinces. Yet, local government's role is growing in the governance of federal systems and creating new interests on the philosophy and model of federalism, resulting in changing its position alongside the new role (Steytler 2005).

It clear that there is a lot we do not know, and need to know, to effectively address the present corona virus pandemic. Hence, this paper examines the role of local governments in containing coronavirus (COVID-19) epidemic in Oromia regional state (one of the constituent units of Ethiopian federation) and Addis Ababa City Administration (the capital of the country). It will analyze the efforts made by the local governments in containing coronavirus pandemic based on their powers and functional competences.

\section{Objectives of the Study}


The main objective of the study is to assess the role of local governments in containing the COVID-19 pandemic in the context of the federal system. The specific objectives are:

- to examine the responsibility of each level of government for containing the corona virus disease under the country's federal dispensation,

- to assess the activities of each level of government in containing the virus in relation to the Constitution and the federal system

To assess the extent to which local governments are recognized under the FDRE constitution, and to explore how much power and competencies are given to them to recommend future policy direction to build strong local governance in Ethiopia

Significance of the Study

Recently many developing countries have recognized decentralized governance as a factor for local development and promoting good governance. Similarly, the process of decentralization in this country is of a recent phenomenon. Rural woredas and municipalities/ towns have started getting attention because they are assumed to play key roles in local, regional and national development. Since these tiers of government are close to community, they have substantial importance for mobilizing local resources for social and economic development, and for controlling different pandemics such as COVID-19. Hence, local governance is likely to be especially important in bridging the gap between policy measures and local realities for the coordination of responses to COVID-19.

Since the main purpose of this study is to provide information about local governments' role in containing coronavirus epidemic and the practice in Ethiopia in line with the performance of decentralized local governance, it will assist federal, regional and local policy-makers, planners and program implementers to acquaint with current knowledge about the status of local governments to avoid rebirth of COVID-19 infections and of similar pandemics in the future.

\section{Methodology of the Study}

Descriptive and exploratory research approaches were utilized in the study to richly describe and to investigate an under researched corona virus (COVID-19) pandemic issue in the local governments of Ethiopia. The research is an exploratory method of observation to gather non-numerical data and an inductive process of organizing data in to categories and identifying patterns. Qualitative research approach was used to establish holistic process and largely narrative description to understand the COVID-19 pandemic in the local governments.

Both primary and secondary data sources were used. Primary data were collected using interviews from civil servants and officials in the local governments. The secondary data were collected from different constitutions, proclamations, regulations, and unpublished documents and reports. The research sites were purposely selected from Oromia (Sebeta Hawas woreda, Burayu town, Batu town, Goba woreda, Bishoftu town) and Addis Ababa (Yeka and Gulele sub-cities). They were selected both from the center and periphery areas to represent both areas. Interview participants were selected based on the convenience for interview. Interviews were also conducted through telephone as the situation was not convenient for face to face interaction of persons due to the coronavirus (COVID-19) pandemic in all the areas in the country. 


\section{Conceptual and theoretical issues}

\section{Devolution of Power and Development}

Decentralized systems of governance have been introduced in many states since 1990s due to the unsatisfactory performance in achieving national objectives through centralized processes. The failure of central political systems in several developing countries also contributed to the decentralization of powers to lower level government tiers (Abu, 2003; Deribe, 2015). According to Abu (2003:111), "the failure of the centralized system of economic and political administration is one of the forces behind the temptation of a number of countries to experiment with some forms of decentralization of both political and fiscal power." The reactions to extreme centralization in certain unitary states also led to the dissemination of federal or decentralized systems in the world (Ahmad and Brosio, 2006). Decentralization is vital to advance service delivery, react to the public interest and demand of the civil society, resolve conflict, address the technological changes and meet the challenges of the growing urbanization. Decentralization of governance is largely held to promise a range of benefits since the centralized state has lost a great deal of legitimacy everywhere due to its various well-accepted failures (Ahmad and Brosio, 2006). Such reactions have led to demands for more responsibilities and resources for subnational governments.

The contemporary global politics also urges to get economic and political systems closer to local people by encouraging subnational governments to engage in political and economic practices. Public services delivered to persons must at least be administered by agencies close to those being served. For example, hospitals and schools must be administered by managers who have some degree of discretion over expenditure decisions, and local services such as sanitation, water, recreation, and garbage are almost always delivered by local governments (Boadway and Shah, 2009). Hence, sharing central authority, introducing more intergovernmental competition and checks and balances is often advised as a way of reducing the role of the state in general. It is viewed as a way to make government more responsive and efficient.

Devolution of power has many goals, out of which developmental and democratic goals can be cited. According to Zemelak and Asefa (2012), the worth of local government as an institution of democracy and development is getting acknowledgment in the past few decades. For example, local government is recognized in South Africa as a leading actor in entrenching democracy and promoting development (Steytler, 2005). The Indian Constitution in 1992 was also driven by developmental concerns. Local government has also been frequently recognized as a vital strategic sector for enhancing governance and development in Bangladesh (Aminuzzaman 2010). For Aminuzzaman, local authorities work with their community to enhance social, economic, environmental and cultural wellbeing now and for the future.

Decentralization enhances the quality of representation which enables people to participate more effectively in development. In essence, decentralization strengthens democracy by enhancing the government's institutional ability to determine and respond to people's choices. Through decentralized institutions, minorities and vulnerable members who may otherwise have a weak or non-existent voice at the national level are more effectively represented thereby enhancing participation in development (Malik, 2013). Hence, decentralization is believed to be a best mechanism to bring government closer to 
people and to promote development and institutionalize democracy in addition to being a political process of creating accountability.

Development is improvement in citizens' well-being, popular participation, social justice and equity. Development is achieved when poverty is eliminated or reduced by making the food, health, clean water, education, etc. accessible to the public at large. These broad development goals are realized through the process of devolution of power and empowerment of the local governments. To bring about participatory development that can stimulate the welfare of citizens, there needs to be decentralized and empowered local governments (Ayele and Fissha, 2018). However, Steytler (2005) argues that a three-sphere of government each functioning with some degree of autonomy may create complex relationships among the different levels of government. It may also influence the effectiveness and efficiency of government, the problems most decentralized countries share. Better governance is critical for fighting infectious disease transmission in this globalized world. As complex as the epidemic itself, infectious disease control presents significant governance challenges. It is thus vital to understand how states place themselves in the architecture of global epidemics control. Governments need to set up a functional system to face up the challenge. Timely interventions with high political commitment and community mobilization are believed to assist in preventing the incidence of numerous cases and deaths. Local governments also have great roles in the governance. Without real functioning local governments, the role of states in controlling global infectious diseases cannot be realized.

\section{The Place of Local Governments in Federal Systems}

Locality can create a foundation where common interests could be negotiated with other areas and levels of governments such as federal and regional governments. Goss (2011) describes identity, geography, scale and power as the elements that make up localities. In this study the term 'local' refers to rural and urban governments i.e. woredas and towns in Ethiopia. The role of local governance is not simply to work at local level, but negotiate relationships with other levels of governance. Governance in the sense of network of decision-making and relationship between levels of government and between government and people is required at local level (Goss, 2001:32-36). Local governance is not just concerned with the local, but about the interface among levels of government i.e. federal, regional, local and neighborhood. If vicinity is too small it might not be adequately powerful to be listened to by others. Local governments need to have adequate power to be able to negotiate. They need to have greater capacity to listen to and to respond to public concerns and to negotiate and create partnership with different organizations operating in their localities (Nigussie Daba and Mberengwa, 2009). Local governments should respond to administrative issues and focus on quality, effectiveness and responsiveness, and adjust them to their specific situations (Stewart and Stoker, 1995:9).

Local governments in federal systems do not have similar place and role as some federations constitutionally recognize their local governments while others leave such functions and competences for the regional states or provinces. In many federations, local governments are regarded as the competences of the states or regional governments. Countries with a federal system of governance also differ significantly in terms of federal influence on subnational governments and vice versa. In some states central control over regional expenditures is rather restricted, and sub-central units have substantial power to 
decide their matters. In others, central and sub-central institutions are noticeably separated and the national and subnational governments interact through gatherings of administrators and ministers (Boadway and Shah, 2009). Ahmad and Brosio (2006) are also of the view that states with a strong legal framework and new institutional methods, including the dispersal of asymmetric arrangements have emerged as a result of decentralization of powers.

The constitution of the United States of 1787, the Swiss Constitution of 1848, the Australian Federal Constitution of 1901 and the Canadian Constitution of 1867 did not include local government as an order of government. Most of them were silent on the matter, or mention it only as a provincial field of competence (Steytler, 2005). However, after the Second World War, the issue of local self-governance growingly appeared in federal constitutions, frequently matching with the return to democratic rule. Although the Spanish Constitution of 1978 focused on the creation of Autonomous Communities, local autonomy was nevertheless mentioned. The first was the Constitution of the Federal Republic of Germany of 1949. Yet, local government's role is growing in the governance of federal systems and creating new interests on the philosophy and model of governance and federalism, resulting in changing its position alongside the new role (Steytler, 2005). According to Steytler, Spain, Brazil, India, Nigeria and Switzerland have entrenched local government in their more recent constitutions. Within the constitutional setting, the roles of local governments are defined in detail by provincial statutes in Canada (Lazar and Seal (2005). According to the authors, every sub-national unit has its own regulation labeling the place, authorities and responsibilities of urban administrations within its area.

Local Governments are usually the first line of link to the communities they serve (Aminuzzaman, 2010). They play a key role in administrative, public service delivery and developmental roles. They also establish healthy and safe work environment, create jobs, contribute for sustainable local economic development, and a stable political climate (Ketema and Regassa, 2018). We can see the growing role of local governments in the delivery of services to the local community. Ever more tasks are being transferred to the local governments as they are becoming instruments for growth and development in many countries. This could also put substantial pressure on them to finance such tasks. These increased status and role of local governments make intergovernmental relations between local, state/provincial and federal governments more complex. In addition, decentralization can also be considered as an instrument of good governance. Local governance increases the popular involvement in decision making, enhances local people's capacities, and improves responsiveness, transparency and accountability of all levels of government.

\section{Findings of the study}

\section{Powers and Functions of Local Governments in Ethiopia}

The Ethiopian 1995 Constitution assures that the federal government and the states shall have legislative, executive, and judicial powers. In addition, the Constitution in its article 50(b) clearly stipulates that their powers of policy making are constitutionally delineated and that they shall respect their powers. In this regard, the Federal Government formulates overall economic, social, and developmental policies. The federal constitution provides that general policies related to social and economic matters, after being prepared by the executive council, have to be approved by the parliament. The executive council is 
also ordered to ensure the implementation of the policies once approved by parliament. Likewise, the regional policies on social services and economic development are formulated by regional executive council and submitted to a regional council for approval. Article 52 (c) of the FDRE constitution also empowers the regional states to formulate and execute economic, social and development policies, strategies and plans of their respective governments. The 2001 revised constitution of Oromia regional state in its article 49 (i) also empowers the Council or 'Caffee' to adopt social and economic policies, strategies and plans of the region. According to the Constitution, the legislature or 'Caffee' is decisive institution in policy making process in the regional state. The council/'Caffee' is the highest political body with full powers in the affairs of the regional state and mandated to check whether the laws, policies and strategies are implemented by the executive according to their intention and desire, including the power of calling and questioning the executive bodies of the regional state. Getting the power to formulate policies on local development issues is also critical for local governments (woredas and cities).

However, the place of local government in the Ethiopian federal system is not clear. Local governments in Ethiopia do not have adequate protection under the FDRE Constitution. The functions under the competences of local governments are not granted by the federal Constitution and are not original. So, the Constitution lacks clarity and the existence and status of local governments is based on the interests of the powerful party at the federal and regional levels rather than on Constitutional doctrines. The regional constitutions also did not explain whether woredas may formulate and adopt policies on the local development matters. On the other hand, federal and regional cities have policy making power which is based on proclamations and other legal instruments rather than federal and regional constitutions.

Addis Ababa city Administration Proclamation No.35/2012 also states that "The City Government shall have Weredas that are organs of a Sub-City." This shows that woreda stays a body hierarchically subsidiary to the city government. When local institutions are designed as agents of the regional states to achieve the regional goals, such conditions may create a central tension in the tasks of local governments. Zemelak (2014) stated that a multi-tiered system of rural local government is established in which each level is allowed to choose its own local issues related to social and economic development, but the exact matters on which it is empowered to act are not clear.

Communities and local businesses are all facing unique challenges and stress during this time of COVID-19 and are increasingly looking to the local councils for help. Yet local governments could not have adequate budgets for crisis management which may create extra financial burden on them as they remain to provide necessary services and assist their communities. As elected governments, local governments have a democratic responsibility to pursue the objectives of their constituents. Hence, empowering local governments with strong, self-governing authority and power for locally demarcated objectives, rather than making them simply as institutions formed by the states, is critical to assure their permanence.

The crisis may also bring certain positive effects to local governance in spite of the negative consequences of the COVID-19 pandemic. Citizens could be reminded of the essential role of public institutions and the need for a robust local government to respond to challenges like the corona virus epidemic. This awareness, in the long term, may strengthen local participatory processes, accountability and transparency. Moreover, the 
current pandemic offers a chance for local governments to rethink how to best serve citizens through digital tools (Moolakkattu, 2020). COVID-19 could open the door to a long-due digital transformation of public institutions based on accountability, open data and democratized access to information for everyone.

On the other hand, woredas are empowered to prepare their own social and economic development plans by regional constitutions. The regional constitutions provide that a woreda has the necessary power to plan and implement its own social services and economic development (Constitution of Oromia Regional State, 2001). To this effect a woreda executive council is mandated to prepare plans on woreda social and economic issues, and the concerned woreda council is sanctioned to adopt the plans. But woreda planning is not plainly clarified by the constitutions (Zemelak, 2014). Woreda planning is mostly based on the guideline of Ministry of Finance and Economic Cooperation and Civil Service Commission. Planning involves identifying resources and developmental priorities, and utilizing resources to achieve these priorities. Woreda development plans can be classified into short-term development plans (for 1 year), medium-term or strategic development plans (for 3-5 years) and long-term development plans (for 10-20 years). Woredas are authorized to adopt a short-term and medium term plans.

The constitution at first sight seems to be ambiguous about the constitutional status of local governments. In 2001, a decision was made to decentralize power to local authorities. It might even appear to suggest the establishment of a mere deconcentrated local administration by the regional states as opposed to democratically elected autonomous local governments. Yet, a cautious scrutiny of the constitution reveals that the latter requires the establishment of autonomous local government. However it needs to be known that the ostensible ambiguity in the constitution regarding the status of local government has made uncertainty about the status of local government. In addition to this, the absence of clearly defined powers, inadequate financial sources, and one party's dominance at all levels of government have stuck the attainment of a constitutionally recognized autonomous local government.

Article 50 (4) of the FDRE Constitution states that the regional governments will grant powers to local governments which indicate that the degree of powers of local governments depends on the regional states as they are the primary guardians of the powers devolved to local governments. The Constitution infers that a specific function should be assigned to local government if public participation is vital for its implementation. For Zemelak (2014), this is based on democratic value for those who have direct interest to deliberate on a public service. Regional states in Ethiopia also adopted regional constitutions in 1995 and revised them in 2000 as the older constitutions did not conform to the FDRE Constitution's recommendation of creating autonomous local governments in the states because local governments were viewed as states' administrative agents (Zemelak, 2014; Zemelak and Solomon, 2018).

Revision of the state constitutions were also necessitated due to the need for empowerment of local governments as the latter were expected to play a key role in achieving poverty reduction and sustainable development goals through the delivery of public services such as drinking water, health services, primary education, etc. at the local level. Revisions of the constitutions were needed to devolve certain functional competences. However, the state constitutions did not spell out the competences of woredas. They just state that woredas can plan and implement social and economic 
development related matters in their localities, without outlining the pertinent functions (Zemelak and Solomon, 2018).

Legal instruments such as proclamations and executive regulations were also used by certain regional states in Ethiopia, such as Oromia regional state, to describe local government functions. However, such documents are below the regional Constitution in the order of regional laws. Furthermore, such proclamations and regulations can simply be revised by the regional states. As a result, the regional states may take back whenever they need, the functions they have reassigned to local governments, because those functions of woredas and towns are not clearly stated in the federal and regional constitutions.

The main reason for the revision of the Oromia State constitution in 2000 was also indicated in the preamble of the revised constitution. The objective was to ensure good governance through separation of state powers such as state councils and the executive organ. Strengthening check and balance, transparency and accountability of state organs and effective state structure to enable them provide effective service was also stated to be the intention of the revision of the constitution. It was also specified that the objective reality of the region could not be met with the existing constitution (Zemelak, 2014).

In addition, regulating local governments in the region was also mentioned as one of the reasons for the revision of the constitution, though the main reason behind the revision of the constitutions of the regional states (including Oromia regional state) was linked to the then strong interest and decision of the ruling party and the central government (Zemelak and Solomon, 2018). Thus, the power to design policies on local issues is an important political power. The power to adopt policies is also important issue in Ethiopia because social and economic policies adopted by different levels of government have a legal force which comes from the process through which they are adopted.

\section{The Role of Local Governments in fighting COVID-19 pandemic in Ethiopia}

The federal government's power to regulate widespread diseases is stated in the FDRE Constitution of 1995. Article 51(3) of the 1995 Constitution states that, the federal government "shall establish and implement national standards and basic policy criteria for public health, education, science and technology as well as for the protection and preservation of cultural and historical legacies". Hence, the federal government is mandated to create and execute nationwide standards and basic policy criteria which the regional governments utilize as a source to frame their policies under the "framework concurrency". It is clear that issues related to public health are concurrent competences of both federal and regional states. As a result, "the federal government has policy making and legislative powers on pandemics as it is a public health issue”. Furthermore, the federal government is also responsible for regulating the mobility of people in the country's borders to control the expansion of the pandemic which may be exacerbated as a result of movement of people around the borders. In this regard, the federal government is expected to play active role by managing the country's borders to contain the pandemic which is a threat to health.

Likewise, the regional policies on social services and economic development are formulated by regional executive council and submitted to a regional council for approval. Article 52 (c) of the FDRE constitution also empowers the regional states to formulate and execute economic, social and development policies, strategies and plans of their respective 
governments. The 2001 revised constitution of Oromia regional state in its article 49 (i) also empowers the Council or 'Caffee' to adopt social and economic policies, strategies and plans of the region. According to the Constitution, the legislature or 'Caffee' is decisive institution in policy making process in the regional state. The council/'Caffee' is the highest political body with full powers in the affairs of the regional state and mandated to check whether the laws, policies and strategies are implemented by the executive according to their intention and desire, including the power of calling and questioning the executive bodies of the regional state.

Ethiopia faces unprecedented devastating and existential challenge even more than most of the world due to the Corona virus unless decisions are guided by evidence, knowledge and good judgment. Without informed decision of the government, the Ethiopian economy may face an enormous shock and the potential consequences could be so catastrophic. Alemayehu Geda (2020) calls for a special and bold politico-economic approach to the challenge and to avoid the cliff. He also advises Ethiopians, the government and opposition political parties to put aside their differences and unite on the pandemic as one people, one country, and also to use the chance to forge the unity of the country. The Ethiopian government has also been investing in economic stimulus packages and emergency healthcare. These interventions denote an unprecedented challenge for governments. While the magnitude of the challenge and policy responses vary across borders, the focus needed at the household and community level highlights the pivotal role local governments must play in response to a crisis. Many of the important services are supplied by the local governments since they are near to the grass roots community. This may involve a high degree of interaction with vulnerable members in the communities through their provision of services such as public health and aged care, meals, and other community services. For the period of the coronavirus epidemic, local governments are likely to assist and implement the federal and regional governments' restrictions concerning their societies necessitating to be social distancing and self-isolating.

It was also stated in Regulation No.466/2020 that no federal or regional level authority can give statement about coronavirus without the permission of the ministerial committee or its sub-committee (FDRE Council of Ministers Regulation No.466/2020). The task force mainly engages in mobilizing the resources and community, awareness creation, distribution of alcohols, sanitizers, soaps, etc. for the needy people, restricting meetings and facilitating conditions for persons to wash their hands, and advising them to wear face masks and/or gloves. This shows that the role of local governments is insignificant as every activity is under the command of ministerial committee. Information from key informants during interview reveals that activities are all managed from a central point by putting in place a centralized task force from federal to local levels for transmitting clear messages from one source. A task force created a central management and coordination point for the coronavirus pandemic response, especially during emergency times. The task force, having a governance structure for decision making around the pandemic, was meant to co-ordinate all the different activities that are required.

The task force creates awareness based on the directives and manuals prepared by the Health Ministry and regional health bureau and passed to them. However, an interview with Oromia regional health bureau expert revealed that no guideline was prepared at the regional level but the bureau sends to the local governments and sectors different documents prepared by the federal ministry of health. The role of regional bureau is very 
much limited as compared to the role of ministry of health (an interview with Oromia regional health bureau expert). If any COVID-19 patients yield to the infection at home, local governments will assure that final resources are performed as per provision mentioned in the directives. The task force prepares list of vulnerable groups like elderly, malnourished and people with immuno-compromised conditions like cancer, diabetes, HIV/AIDs, hypertension and adopt safety measures to prevent them from contracting virus. In such a backdrop, local governments should coordinate with health institutions under its authority to notify the Federal and regional health authorities for managing the drugs, equipment and reagent. This may prevent such groups from the unwanted psychological effects like depression, loneliness, anxiety and suicidal thoughts.

An interviewee from Oromia health bureau also indicated that the coronavirus pandemic related activities are monitored mainly by the Oromia regional bureau in addition to the established regional and ministerial committee. It was also stated that regional health bureau regularly interacts with woreda and city health institutions even before the COVID19 pandemic outbreak. Thus, local governments in the region rely on the senior level of governments (regional and federal governments) for many of the pandemic related issues rather than deciding for themselves. Central supervision of the tasks of local governments is important for achieving decentralized goals as well as national and regional objectives. Collaboration between governments at all levels is also vital to minimize overlapping of activities and duplication of efforts. Interviewees from Addis Ababa also indicated that collaboration between stakeholders is immense in managing crisis like COVID-19. According to the interviewees, local institutions and CSOs in particular had been involved in sensitizations and reaching out for the poor that relied on daily labor to make ends meet. However, the regional constitutions and the city proclamations highlight the tiered relationship of local governments to regional governments than cooperation. Regulation No.466/2020 also states that no federal or regional level authority can give statement about coronavirus without the permission of the ministerial committee or its sub-committee

Local governments in Oromia regional state also discuss COVID-19 related issues on regional media such as Oromia Broadcasting Network, Radio, and local FM stations to raise the awareness level of the community. This may also help to instill positivity and hope, and to guide the public during difficult time of epidemic. However, unlike Addis Ababa city residents who have access to various print and broadcast media, a large part of the people living in rural areas in Ethiopia does not use media due to limited access to such media platforms that are utilized to announce COVID-19 prevention procedures and actions. Moreover, without aggressive interventions, current levels of access to water and soap are suboptimal to adopt the hand-washing recommendations, particularly in rural areas. The limited size of families with different infrastructures such as electricity, refrigeration, or internet access and the relatively high incidence of spouse violence warn that applying the stay and work from home actions could be problematic (Kaleab, 2020). Interview participants in Addis Ababa also stated that during the state of emergency there were different groups that were involved in provision of food and sanitary supplies which seem to have decreased currently. Interviews' reports also show that woredas and subcities are the most crowded places as most activities are concentrated there. Although personal protective equipment are available, considering the overwhelming crowds of clients, lack of ventilation and limited office space, we can say there is potential risk. 
Thus, the role of local governments, especially woredas is critical to slow down the transmission of the virus and to prevent transmission to rural areas. Communication platforms and messaging will need to be adapted to different local realities to make any COVID-19 containment recommendations operational. Local governments need to address barriers to staying at home and support the public in providing different facilities to prevent the virus. The local governments' role is important to end the current pandemic in Ethiopia, as well as similar pandemics in the future addressing the serious challenges related to water, sanitation and hygiene that need urgent attention. Local governments should also collaborate with non-governmental and community-based organizations to strengthen their capacity during COVID-19 outbreak.

We can see that the federal government has broad policy making power, and as a result, can impact local government actions. Its policy making power on social and economic development related issues and establishing and implementing national standards and basic policy criteria for public health, education, science and technology enables it to influence local government undertakings (FDRE Constitution, 1995). This constitutional power helps the federal government to regulate the local governments. The federal government also uses federal policy papers and its legislative powers to regulate local government activities (Zemelak, 2014). The regional governments also regulate local governments through their regional policies and plans. Hence, both senior levels of governments are playing key roles in local governments' actions during this time of coronavirus pandemic through the established task forces at the federal level, and the role of local governments is limited only to implementation.

The federal government also ensures whether the federal standards are achieved or not by the local governments indirectly through the regional states i.e., monitoring through each federal ministry. The federal government could, directly or indirectly support the local government to ensure the execution of central government's policies on social services. The regional governments and zonal administrations also oversee the activities of local governments through the respective sectoral bureaus. At the same time, local governments should work with non-governmental organizations running in their local level to work with them and to focus and invest on COVID-19 response by forging coordination with local government. The woreda executive council is in charge of formulating woreda plans while the woreda council has the final power to approve the plans (Zemelak, 2014). Planning also comprises pinpointing resources and developmental priorities, and using resources to realize the priorities. Article 79 (C) of the revised constitution of Oromia (2001) also states that woreda councils have the powers and responsibilities to create the favorable conditions to mobilize and initiate the public for development actions.

Woredas identify community problems and prioritize them through consultations with the public and incorporate them into short-term plans. However, local governments may not have adequate budgets in their plans for crisis management. This may also create additional financial pressure on them as they continue to deliver essential services and support their communities. Hence, local communities and local businesses could all face unprecedented challenges and stress during the COVID-19 outbreak and may increasingly look to the local councils, community based organizations, non-governmental organizations and private businessmen for help.

Interview results reveal that task forces as subcommittees of the regional committee were established in all these woredas and towns and they are actively participating in 
mobilization of resources by coordinating private investors and the community. It was also reported during interview that the resources provided helped the local government authorities to keep quarantined people in the woredas and towns in a proper conditions with suitable and distinct sleeping accommodations, washing and restrooms for men and women. Similarly, safe water and frequent cleanliness were ensured as different sanitary pads were also easily found and provided to the isolated persons.

On the other hand, the alignment of task forces at all levels (federal, regional, zonal, woreda/town and kebele levels) and the uniformity of the activities in all woredas and towns indicates a top-down approach where the role of local actors is limited to only implementing decisions made at the higher level. In addition, Proclamation No. 3/2020, Article 3(3) states that "any federal or state law, decision or practice which contravenes the emergency declaration shall be of no effect." Hence, the local governments do not have ordinary competencies in time of peace let alone policy decision making power in time of emergency. Quarantine centers in local towns and woredas may face difficulties in collecting necessary food materials. Local authorities in the local governments may need to collect food items including fruits and vegetables from local farmers to fulfill the demand at the quarantine centers to ensure healthy food during this difficult time. Although diets and supplementary foods by themselves cannot prevent COVID-19 infection, balanced diet and good food habits certainly strengthen a person's immunity.

Interview participants indicated that efforts were made to share meals (ye ma id megarat in Amharic), to solve the shortage of food items that could face the areas due to the epidemic. Interviewees also explained that the private sector and non-government organizations operating in their localities are actively engaging in the fighting of the pandemic by contributing different resources in cash and in kind. For instance, the businessmen in the woredas and cities provided different vehicles and buildings for using them for quarantine purposes and related services. Hence, local governments are struggling to respond to the desires of the local communities by utilizing resources obtained from different sources under their disposal though their autonomy is too much limited. For example, a key informant from Goba town explained that the task force divided the GobaMarket into seven places to minimize gatherings of people.

The Regional constitution of Oromia of 2001 does not clearly state whether woredas can formulate their own policies on local development issues. So, it is not clear whether they have powers of policy making or not. The key informants engaged in the interview were also of the view that the role of woredas and towns is implementation of different programs and projects prepared at federal and regional levels, rather than adopting their own policies. This shows low awareness level of the public on policy making power since most people perceive policy making power is limited to the higher level of government. In addition absence of clear policy making power of the local governments in the regional constitution downgraded the lower levels of governance as the sheer policy implementing institutions. This affects local governments' role as laboratories of innovative ideas as the local governments would be able to come up with novel ideas and new methods of confronting local problems such as coronavirus (COVID-19). When the local governments are entitled to adopt their own policies on local issues within their competence, they may tackle the problem in different ways based on their local context. All local governments with diverse contexts may come up with different methods out of which the best can be selected. With the power of policy making, the COVID-19 pandemic 
could offer a window of opportunity to the local governments to create new ideas to protect similar pandemics for future and provide better public services for the local communities. To materialize such opportunity, the regional constitutions should be revised and explicitly state policy making powers of local governments and the local governments must exercise their authority and execute the responsibility of strengthening local development and smooth operation of basic public services including health services. Furthermore, local governments need to develop their capacity in terms of human resource capacity and financial capacity.

Although regional constitutions are silent on whether woredas may enact laws on their social and economic problems, the principle of subsidiarity implied in the regional constitutions permits them to exercise any power that enables them to formulate and execute social and economic development plans. However, absence of clearly stated legislative power in federal and regional constitutions may restrict woredas' important local autonomy of translating locally generated policies into law. This may also limit woreda council's lawmaking power of regulating the council's own internal procedure of operation. This calls for the amendment of the regional state of Oromia's constitution to provide woredas with unequivocally specified and constitutionally provided legislative power.

According to the interviewees, some traders have increased the price of goods and services in the localities taking the COVID-19 situation as a good opportunity. In addition, some restriction measures were also put in place by the federal and regional governments to curb the spread of coronavirus infection. As a result, supply of vegetables, fruits, bread and other food items had been impacted. Key informants during interview explained that local governments (zones, woredas and cities) took legal measures on these illegal traders. Directing woreda police and other security forces is one of the competences of the woreda. The regional cities also exercise both state and municipal functions as these are their functional competences. They also deal with economic issues such as delivering trade licenses, registration and regulation of commercial activities, micro-and small scale enterprises and expanding urban transport infrastructures (Zemelak, 2014) and legal measures taken by the local governments on illegal traders could be related to these functional competences. The Oromia regional state also dispensed a regulation which looks for defining in detail woreda and kebele functional competences in 2003. However, such legal instruments are easily changeable by the regional state as they are ranked below the regional constitution and proclamations in the hierarchy of laws. Hence, woredas and cities in the region can and are exercising certain functions in the security and economic sectors though those functions are not originally emanated from the federal constitutions, and some of them are not also explicitly stated in the regional constitutions.

Participants of the interview also raised that lack of clearly defined activities performed at the level of woredas and towns is a problematic. The federal democratic republic of Ethiopian government declared a national state of emergency on 8 April/2020 to counter and control the spread of COVID-19 and to mitigate its impact (Proclamation No. 3/2020; FDRE Council of Ministers Regulation No.466/2020). The Oromia regional state has also imposed a restriction measures on public transportation on Monday, March 30, 2020 in an effort to contain the spread of the coronavirus (COVID-19) in the region. It was explained by participants of the interview that, as of Tuesday, March 31, it remained unknown how long the restriction would remain in effect for. They also said that the 
restrictions on mobility of persons were lacking precision and clarity, and were not clear whether they were meant to have the force of law.

The restriction on the mobility of rural people to towns and urban residents to rural areas was also announced to the public through a press release. In addition, no reference was made to the specific legal authority on the basis of which these measures were introduced. The lockdown could lead to the freezing of social and economic activities involving severe restrictions on freedom of movement, the right to work/livelihood, freedom of religion, freedom of assembly and freedom of association, and addressing the socio-economic impact of the various measures limiting movement and economic activities of the persons requires the government additional budget. Moreover, limiting rights and freedoms of persons is only possible by constitutional authority with proper procedure of State of Emergency. According to Articles 108 (1), (2), (3), (4) and 109 (1) and (2) of the Oromia regional state constitution (2001), the regional government has the power to decree a state of emergency when the natural disaster or an epidemic happens in the region. The Oromia regional state could announce measures in response to COVID-19 on the basis of a declaration of a state of emergency. The administrative council (the executive arm of the government) of the regional state could prepare and submit a bill to the 'Caffee" Oromia (legislative body of the regional government) for approval, declaring a state of emergency within a framework of Article 93 of the Federal Constitution of Ethiopia.

\section{Conclusion and recommendations}

\section{Conclusion}

The federal government has broad policy making power, and as a result, can impact local government actions. This constitutional power helps the federal government to regulate the local governments. The regional governments also regulate local governments through their regional policies and plans. In addition, both senior levels of governments are playing key roles in local governments' actions during this time of coronavirus pandemic through the established task forces at the federal level. Hence, the role of local governments is limited only to implementation. The alignment of task forces at all levels (federal, regional, zonal, woreda/town and kebele levels) and the uniformity of the activities in all woredas and towns indicates a top-down approach where the role of local actors is limited to only implementing decisions made at the higher level. This affects local governments' role as laboratories of innovative ideas as the local governments would be able to come up with novel ideas and new methods of confronting local problems such as coronavirus (COVID-19). When the local governments are entitled to adopt their own policies on local issues within their competence, they may tackle the problem in different ways based on their local context. All local governments with diverse contexts may come up with different methods out of which the best can be selected. With the power of policy making, the COVID-19 pandemic could offer a window of opportunity to the local governments to create new ideas to protect similar pandemics for future and provide better public services for the local communities.

Woredas identify community problems and prioritize them through consultations with the public and incorporate them into short-term plans. Woreda councils have the powers and responsibilities to create the favorable conditions to mobilize and initiate the public for development actions. However, local governments may not have adequate 
budgets in their plans for crisis management. This may also create additional financial pressure on them as they continue to deliver essential services and support their communities. Thus, local communities and local businesses could all face unprecedented challenges and stress during the COVID-19 outbreak and may increasingly look to the local councils, community based organizations, non-governmental organizations and private businessmen for help.

Although regional constitutions are silent on whether woredas may enact laws on their social and economic problems, the principle of subsidiarity implied in the regional constitutions permits them to exercise any power that enables them to formulate and execute social and economic development plans. However, absence of clearly stated legislative power in federal and regional constitutions may restrict woredas' important local autonomy of translating locally generated policies into law. This may also limit woreda council's lawmaking power of regulating the council's own internal procedure of operation. This calls for the amendment of the regional state of Oromia's constitution to provide woredas with unequivocally specified and constitutionally provided legislative power. The regional states can impose a restriction measures to contain the spread of the coronavirus (COVID-19). However, the restrictions of Oromia state region on mobility of persons were lacking precision and clarity, and were not clear whether they were meant to have the force of law. Limiting the rights of citizens is impossible without following appropriate procedure of state of emergency. and addressing the socio-economic impact of the various measures limiting movement and economic activities of the persons requires the government additional budget.

\section{Recommendations}

Declaring state of emergency following the procedure on the regional constitution was appropriate rather than simply giving a press release. Hence, the regional governments needs to show commitment for transparency, accountability and rule of law when taking such measures as all those measures have far reaching consequences on civil liberties and socio-economic rights of citizens. The laws also need to be enshrined in dully enacted law of general application. Attention must also be paid to what can be done to avoid resurgence of COVID-19 infections and of similar pandemics in the future. The COVID-19 pandemic can serve as an awakening to invest more in local governments, in building their capacity in the long term since pandemics such as COVID-19 are complex social and behavioral challenges that cannot be contained only by national governments. In addition, effective coordination mechanisms between national and local governments are critical. Strengthening local governments (rural woredas and urban centers) and building the capacity of local administrators and bureaucrats to manage the policy response (from health to the economy to social protection) is critical. Hence, investment in local government should be given attention to effective recovery and long-term resilience.

There is a need to create awareness for regional states on their constitutional mandates and importance of local governments. The regional governments need to show commitment and follow the procedure on the regional constitution for transparency, accountability and rule of law when taking such measures as declaring state of emergency. Furthermore, there is a need to constitutionally establish local governments and put specific competencies unto them. 
Citizen Participation mechanisms need to be devised for mobilizing resources and to work with local agencies. Community and religious leaders and trusted and credible third parties play important roles in the local communities and their support is needed to spread awareness, particularly in remote and vulnerable communities because public action in response to a crisis mitigates its impact. Robust accountability such as independent media allow citizens to check that emergency resources are distributed equitably and used optimally.

\section{References}

1. Addis Negari Gazeta of the City Government of Addis Ababa (2012), Proclamation No. 35/2012 The Addis Ababa City Government Executive and Municipal Service Organs Reestablishment Proclamation 2. Alemayehu, Geda (2020).The Macroeconomic and Social Impact of COVID-19 in Ethiopia and suggested Directions for Policy Response: A Policy Brief, Department of Economics, Addis Ababa University

3. $\quad$ Aminuzzaman, Salahuddin M (2010). Local Government and Development in Bangladesh Lessons Learned and Challenges for Improving Service Delivery of Union Parishad (UP).

4. $\quad$ Assefa Fisseha (2018). Local-Level Decentralization in Ethiopia: A Case Study of Tigray Regional State, Ethiopian Journal of Federal Studies, Vol. 5, No. 1, AAU press. https://doi.org/10.1515/ldr-2019-0006 5. $\quad$ Bosire, Conrad M. (2013), Devolution for development, conflict resolution, and limiting central power: An analysis of the Constitution of Kenya 2010, University of the Western Cape (A PhD dissertation). 6. Estrada, Mario Arturo Ruiz and Alam Khan (2020). Globalization and Pandemics: The Case of COVID-19

7. Federal Democratic Republic of Ethiopian Constitution (1995), Federal Negarit Gazette Proclamation Number 1/1995, A.A.

8. Federal Democratic Republic of Ethiopia Federal Negarit Gazette (2020), Proclamation 3/2020, (Article 3(3) A State of Emergency Proclamation Enacted to Counter and Control the Spread of COVID-19 and Mitigate Its Impact;

9. Federal Democratic Republic of Ethiopia Federal Negarit Gazette (2020), State of Emergency Proclamation No. 3/2020 Implementation Regulation, 26th Year No.35, Addis Ababa

10. Goss, Sue (2001). Making Local Governance Work: Networks, Relationships and the Management of Change: New York, Palgrave.

11. Kaleab, Baye (2020). COVID-19 Prevention Measures in Ethiopia: Current Realities and Prospects, Strategy Support Program Working Paper 142

12. Lazar, Harvey \& Aron Seal (2005). Local government: Still a junior government? The place of municipalities within the Canadian federation in Nico Steytler (ed.) The place and role of local government in federal systems Konrad-Adenauer-Stiftung, Johannesburg.

13. Lupu, D., Maha, L. G., \& Viorică, E. D. (2020). COVID-19 Incidence in Europe: Drivers and Government Interventions. Transylvanian Review of Administrative Sciences, 16(SI), 80-93. DOI: http://dx.doi.org/10.24193/tras.SI2020.5

14. Malik, Vidyadhar (2013). Local and Community Governance for Peace and Development in Nepal, Bonn.

15. Nigussie Daba (2017). Public Policy Making at Sub-national level in Ethiopia: the case of Oromia Regional State, Addis Ababa University.

16. Oromia Regional State Revised Constitution (2001), Megelete Oromia, Addis Ababa

17. Rajadhyaksha, Madhavi (2020). Five lessons for local governments during COVID-19 https://www.opml.co.uk/blog/

18. Steytler, Nico (2005). Introduction in Nico Steytler (ed.) The place and role of local government in federal systems Konrad-Adenauer-Stiftung, Johannesburg.

19. Zemelak Ayele (2020). Federalism and the COVID-19 crisis: The perspective from Ethiopia, Forum of Federations 
20. Zemelak Ayele (2018). Institutionalizing Features of a Developmental Local Government, Ethiopian Journal of Federal Studies, Vol. 5, No. 1, AAU press.

21. Zemelak Ayele and Solomon Nigussie (2018). The Constitutional and Legislative Framework for Local Government in Ethiopia. Ethiopian Journal of Federal Studies, Vol. 5, No. 1, AAU press.

22. Zemelak Ayele (2014). Local Government in Ethiopia: Advancing Development and Accommodating ethnic minorities, Bade-Baden: Nomos verlag.

23. Zemelak Ayele and Yonatan Fessha (2012). The Constitutional Status of Local Government in Federal Systems: The Case of Ethiopia, Africa Today, Vol. 58, No. 4, pp. 89-109, Indiana University Press. Creative Commons Attribution - Non Commercial - No Derivatives 4.0 International License. 
